\title{
Hukum Islam dan Perubahan Sosial (Studi Epistemologi Hukum Islam dalam Menjawab Tantangan Zaman)
}

\author{
Muhammad Sulthon \\ UIN Sunan Ampel Surabaya \\ Email : sulthonproling@gmail.com
}

\begin{abstract}
Deconstruction of Islamic law in accordance with the subject matter that is in harmony with the social dynamics become mainstream. This deconstruction is epistemelogi idea is applied in the form of social thought Islamic thinker Islamic law. In the Koran legislation contains general principles and legal-specific. The general principles are the true meaning and arguments behind-specific legal provisions, sometimes explicitly stated also accompany expressions of legal-specific. In the renewal of ideas Islamic law, substantive attention to texts that are definitive (absolute) and zhanni (relative). The distinction between qath'i with zhanni so stressed, because in this case it is an open space for diligence in order to respond to changing times. Deconstruction of Islamic law seeks to find knowledge that is rooted to the moderate Islamic knowledge and adaptive to the times.
\end{abstract}

Keyword:

Ideas Islamic law, social change

\section{PENDAHULUAN}

Kehidupan adalah sesuatu yang dinamis, ia selalu berubah mengikuti irama zamannya. Sementara syariah itu terbatas (al-syaria'ah mutahaddidah), tetapi permasalahan kehidupan terus berkembang (al-waqaiq mutajaddidah). Konsekuensi dari hal tersebut adalah hukum Islam bisa tertinggal dengan permasalahan kehidupan sosial.

Hukum Islam memiliki dua sifat atau karakter, al-tsabat ( tetap ) dan al-tathawwur (dinamis). Al-tsabat artinya tetap, yaitu hukum Islam yang tidak berubah karena perubahan zaman. Sifat hukum ini berkaitan dengan ibadah mahdah. Sedangkan tathawwur artinya dinamis, Hukum Islam yang karakternya seperti ini berkaitan dengan muamalah. Hukum muamalah mengikuti prinsip ibahah, artinya dalam bidang muamalah apa saja diperbolehkan selama ajaran Islam tidak melarangnya atau sesuatu itu tidak diatur secara husus. Hukum Islam yang masuk katagori muamalah sangat banyak, misalnya hukum pidana, perdata, politik, sosial, ekonomi, dan sebagainya.

Gagasan dekonstruksi Hukum Islam sesuai dengan subject matter yang selaras dengan dinamika perubahan sosial menjadi suatu mainsteam.Gagasan ini berkembang memasuki ruang yang cenderung bersifat kultural, yuridis, dan bahkan filosofis. Pemikiran Hukum Islam progresif ini berupaya menemukan pengetahuan yang mengakar mengenai ilmu keislaman yang moderat dan adaptif dengan perubahan sosial, untuk menghasilkan kepercayaan atau keimanan yang puritan, yang selanjutnya terimplementasikan dalam tingkah laku yang dapat dipertanggungjawabkan secara epistemelogis dengan mengacu pada Hukum Islam yang elastis atau amal yang aktif-progresif. Pengamalan Hukum Islam progresif ini menjadi betul-betul progress dengan semangat kepeloporan, karena dalam progresivisme inklusif termuat sifat kritis, yang kritisismenya terlihat dalam tekanan yang kuat untuk membuat distingsi-distingsi, kategori-kategori, analisis, dan sebagainya. Dengan penghargaan yang besar pada peran rasio, landasan progresivisme ini sangat penting dalam menampilkan corak Hukum Islam yang aplikatif dalam realitas kehidupan sehari-hari, responsif terhadap dinamika perubahan dan kemajuan.

Nash telah selesai diwahyukan (alNushush Mutanahiyah), tetapi kehidupan berubah dan berkembang (al-waqaiq ghairu mutanahiyah). Muncul suatu pertanyaan, apakah sesuatu yang dinyatakan selesai itu dapat menjawab sesuatu ( aspek hukum permasalhan kehidupan) yang tidak pernah selesai, terus berkembang dan dinamis. Sehingga ada yang mengatakan hukum ketinggalan dengan obyeknya. Fenomena yang ada adalah orang selalu menggunakan hukum yang sudah ada, tanpa mau bersusah payah melihat cara pengambilan suatu hukum dari sumbernya. Sehingga ketika dihadapkan kepada masalahmasalah baru yang belum ada hukumnya mengalami kesulitan.Dari sinilah dipandang perlu adanya sebuah cara atau epistemologi hukum yang berfungsi menjawab tantangan perkembangan zaman dan dinamika sosial. Inilah yang dijadikan masalah yang diangkat dalam penelitian ini.

Penelitian ini menggunakan pendekatan yuridis, historis, dan filosofis untuk menjawab rumusan masalah di atas. Sementara untuk epistemologis hukum Islam dibatasi pada qiyas dan ijtihad.

\section{PEMBAHASAN \\ Hukum Islam}

Dalam studi atau kajian Hukum Islam era kontemporer, ada banyak hal yang 
menyebabkan munculnya pertanyaan : apakah Hukum Islam bisa atau perlu direformasi, atau apakah Hukum Islam perlu untuk diperbarui dan dirubah sesuai degan kondisi dan tuntutan perubahan zaman?. Penyebab munculnya pertanyaan tersebut adalah karena terdapat penggunaan terma-terma yang mirip artinya ketika membahas Hukum Islam. Terma-terma tersebut berasal dari bahasa Arab dan sering menimbulkan kesalahpahaman ketika langsung dipakai dalamkonteks selain bahasa tersebut. ${ }^{1}$ Supaya tidak salah paham, harus dibedakan antara syariah dan fiqh. ${ }^{2}$

Problem yang muncul adalah dalam bahasa aslinya atau bahasa Arab kedua terma di atas artinya berbeda, sementara penggunaan dalam bahasa Indonesia orang sering menyamakannya. Banyak pendapat para ahli yang mencerminkan adanya perbedaan dua terma di atas. Misalnya Syaltout mengatakan bahwa syariah adalah sebuah aturan yang dibuat Allah untuk dipatuhi hamba-hamba-Nyai. ${ }^{3}$ Pendapat hampir sama disampaikan oleh Faruq Nabhan yang mengatakan syariah adalah sesuatu yang disyariatkan Allah kepada hambaNya. Sedangkan menurut Manna' al-Qathan, syariah berarti segala ketentuan Allah yang disyariatkan bagi hamba-hamba-Nya baik menyangkut akidah, ibadah, ahlak maupun muamalah. ${ }^{4}$ Dengan demikian dapat disimpulkan bahwa syariah itu identik dengan Agama. ${ }^{5} \mathrm{Jadi}$ syariah adalah ajaran Islam yang sama sekali tidak dicampuri oleh adanya nalar manusia. Syariah adalah wahyu Allah secara murni yang bersifat tetap, tidak bisa berubah dan tidak boleh diubah oleh siapapun kecuali oleh yang maha mutlak yakni Allah sendiri.

Secara semantis kata fiqh bermakna mengetahui sesuatu dan memahaminya dengan baik. ${ }^{6}$ Sedangkan secara terminologis, fiqh menurut Abu Zahrah artinya mengetahui segala hukum agama yang bersifat praktis yang digali dari sumber-sumbernya dengan terperinci. ${ }^{7}$ Sementara al-Amidi berpendapat figh adalah

${ }^{1}$ Ahmad Minhaji, "Reformasi Hukum Islam", Aula,Vol III, No. 2, 1994, hlm. 67.

${ }^{2}$ Muhammad Daud Ali, Hukum Islam: Pengantar IImu Hukum dan Tata Hukum Islam di Indonesia. Jakarta: PT Raja Grafindo, cet. XIII, 2013, hlm, 45-51.

${ }^{3}$ Hasbi As-I Shiddiqi, Fasfafah Hukum Islam, cet. IV, Jakarta: Bulan Bintang, 1993, hlm.21.

${ }^{4}$ Fathurrahman Djamil, Filsafat Hukum Islam, cet. V, Jakarta: Logos Wacana Ilmu, 2013, hlm. 7.

${ }^{5}$ Lebih jauh Muhammad Daud Ali mengatakan, bahwa syariah adalah ketentuan-ketentuan atau hukumhukum yang ada dalam al-Quran dan hukum-hukum yang ada dalam Hadis Nabi Muhammad SAW. Lihat: Muhammad Daud Ali, Hukum Islam: Pengantar IImu Hukum dan Tata Hukum Islam di Indonesia, hlm. 42-55.

${ }_{6}$ Abu al-Hasan Ahmad Faris bin Zakariya, Mu'jam Maqayis al-Lughah. Mesir:Musthafa al-Babi al-Halabi, 1970, jilid II, hlm. 442.

${ }^{7}$ Muhammad Abu Zahrah, Ushul al-Fiqh. Mesir: Dar al-Fikr al-Arabi, 1958, hlm. 56. suatu ilmu yang berkaitan dengan hukum agama yang sifatnya hukum cabang yang dihasilkan dari penalaran dan mengambil dalil. ${ }^{8}$

Sehingga definisi di atas mempunyai pengertian bahwa figh bukanlah hukum agama atau hukum syara', melainkan sebuah interpretasi yang bersifat dugaan terhadap hukum agama atau syara'. Sehingga dengan fiqh yang hanya bersifat interpretasi dugaan yang kuat mengenai keadaan di sekitarnya, maka figh dapat berubah sesuai dengan keadaan tersebut.

Adanya kekaburan penggunaan istilah syariah dan fiqh dapat dilihat dalam literatur Barat misalnya, istilah Islamic Law dipakai untuk syariah dan juga fiqh. Hal ini terjadi pula pada literatur bahasa lain, seperti Islamistise Recht dalam bahasa Belanda, Islam Bukuku dalam bahasa Turki, dan Hukum Islam dalam bahasa Indonesia.

Kata Hukum Islam sama sekali tidak ditemukan dalam al-Quran dan literatur hukum dalam Islam, yang ada dalam al-Quran adalah kata syariah, figh, hukum Allah dan yang seakar dengannya. Atau yang biasa digunakan dalam literatur hukum dalam Islam adalah syariah Islam, fiqh Islam dan hukum syara'. 9

Dengan demikian kata Hukum Islam merupakan istilah khas Indonesia yang agaknya diterjemahkan secara harfiyah dari term Islamic Law dari literatur Barat. Dalam penulisan ini diketengahkan dua pengetian Hukum Islam oleh dua ahli, yaitu Hasbi al-Shiddiqi dan Amir Syarifuddin. Menurut ahli yang pertama Hukum Islam adalah hasil upaya yang dikumpulkan oleh ahli figh dalam melaksanakan syariah yang berkesesuaian dengan kondisi masyarakat. Nampaknya apa yang disampaikan oleh beliau ini senafas dengan pengertian figh..

Sedangkan ahli yang kedua, Amir Syarfuddin berpendapat, jia hukum dikaitkan dengan Islam akan mempunyai pengertian seperangkat aturan yang bersumber dari Allah dan Rasul-Nya mengenai perbuatan manusia yang sudah mencapai derajat mukallaf yang diyakini berlaku dan mengikat semua muslim. Dari pengertian yang disampaikan tersebut, dapat ditarik pengertian bahwa definisi tersebut meliputi hukum syariah dan juga hukum fiqh, karena kedua kata tersebut masuk dalam definisi. ${ }^{10}$

Dari dua pendapat tersebut dapat dikatakan bahwa Hukum Islam itu dikatakan tetap dan tidak berubah manakala yang dimaksud itu syariah. Yaitu ajaran Allah dimana kebenarannya bersifat mutlak, lengkap dan

\footnotetext{
${ }^{8}$ Saifuddin al-Amidi, al-Ihkam fi Ushul al-Ahkam. Kairo: Muasassah al-Halabi, i967, jilid I, hlm.8.

${ }^{9}$ Fathurrahman Djamil, op cit, hlm. 11.

${ }^{10}$ Amir Syarifuddin, Pembaharuan Pemikiran Hukum Islam, cet. III, Padang:Angkasa Raya, 2005, hlm.19.
} 
sempurna. Semntara kalau dikatakan Hukum Islamitu dapat berubah dan dikontektualisasikan dengan situasi, konsisi dan zaman, maka yang dimaksud dengan Hukum Islamyang demikian adalah Hukum Islam yang mempunyai arti figh, yaitu sebuah hasil dari ijtihad dan interpretasi ulama terhadap syariah dimana kebenarannya bersifat relatif.

\section{Elastisitas Hukum Islam}

Menurut Ibnu al-Qayyim transformasi hukum Islam secara faktual tidak secara kebetulan dan terumbar liar,melainkan berjalan secara konsinten mengikuti prinsip dasar yang mapan.Transformasi Hukum Islam terjadi selaras dengan transformasi waktu, ruang, keadaan, motivasi dan tradisi. ${ }^{11}$

\section{Prinsip Waktu}

Prinsip ini mengacu pada urgensi dimensi waktu sebagai faktor penyebab terjadinya transformasi Hukum Islam. Namun demikian, Ibnu al-Qayyim tidak menyajikan keterangan lebih lanjut perihal konsep waktu yang dimaksudkan. Walaupun demikian, melalui contoh kasus yang dijadikan pendukungnya dapat diduga bahwa konsep waktu yang dimaksud adalah transformasi waktu dari waktu damai ke waktu perang, dari waktu normal cukup pangan ke waktu peceklik dan kelaparan. Misalnya larangan melaksanakan hukuman tindak pidana pencurian pada waktu perang. Hukuman bagi pencuri dalam keadaan normal adalah potong tangan. Tetapi pada kenyataannya Rasulullah melarang pelaksanaan hukuman pidana potong tangan pada waktu perang. ${ }^{12}$ Ini kemudian diindahkan dan dilestarikan oleh para sahabat seperti Umar bin Khattab, Abu Darada', Huzaifah dan lainnya.

Latar belakang pelarangan ini didasarkan pada kekhawatiran terjadinya ekses yang lebih parah yang tidak disukai Allah dengan pelaksanaan hukuman tersebut dibandingkan dengan membatalkan atau menundanya.

\section{Prinsip Ruang}

Prinsip ini pada urgensi ruang sebagai kunci trnsformasi Hukum Islam yang didasarkan pada kasus-kasus penyelesian hukuman pidana klasik. Kasus-kasus yang dijadikan landasan utuk menjelaskan transformasi ruang sebagai kunci penyebab terjadinya transformasi hukum antara lain pembayaran zakat fitrah sesuai dengan potensi ekonomi wilayah setempat masyarakat muslim. Artinya zakat fitrah dapat

${ }^{11}$ Ibn al-Qayyim, I'lam al-Muwaqqi'in, juz 3. Mesir: Maktabah Tijariyah al-Qahirah, 1955,hlm. 33.

${ }^{12} \mathrm{Abu}$ Dawud, Sunan Abu Dawud, jilid IV, 1998. Bandung:Dahlan Press, hlm. 142. dibayar dengan padi, jagung, biji-bijian lain, bahkan dapat berupa susu, daging, ikan, ataupun komoditi lainnya.

Perubahan tersebut, menurut lbnu alQayyim didasarkan pada semangat yang menjiwai nas (teks syar'i) tentang zakat fitrah yang mengacu pada potensi ekonomi wilayah Hijaz (Makkah, Madinah dan sekitarnya) adalah berupa gandum, anggur, kurma dan kismis. Jenis-jenis komoditas tersebut tidak selalu dikenal di wilayah lain, bahkan banyak wilayah yang tidak mengenal sama sekali komoditas tersebut. Oleh karena itu, yang dijadikan standar baku adalah nilai ekonomi dan nilai konsumtif dari komoditas tekstual tersebut, bukan pada jenis komoditas yang tertulis secara tekstual.

\section{Prisnsip Keadaan}

Prinsip ini selaras dengan dengan transformasi keadaan. Prinsip ini mengacu pada urgensi keadaan sebagai kunci penyebab transformasi Hukum Islam. Untuk memperkuat prinsip ini, Ibnu al-Qayyim menyajikan contoh transformasi hukum thawaf bagi wanita yang sedang haid.

Berdasarkan panduan hadis Rasulullah yang artinya "Lakukanlah apa saja yang dilakukan oleh haji pada umumnya, kecuali thawaf". Pada dasarnya thawaf itu terlarang bagi wanita yang sedang haid. Namun demikian, karena terjadi perubahan keadaan, maka wanita yang sedang dalam keadaan haid pun diperbolehkan melaksanakan thawaf. Thawaf wanita dalam keadaan haid seperti ini tetap dinilai sah tanpa harus membayar dam (denda). Penetapan hukum yang demikian, didasarkan pada pemahaman terhadap hadis tentang pelarangan thawaf bagi wanita haid tersebut adalah ditujukan kepada audiensinya yang dalam keadaan normal dan mampu melaksanakannya dengan mencari alternatif lain. Sedangkan jika keadaan telah mengalami transformasi dan tidak mungkin mencari alternatif penyelesaiannya, maka hukumnya pun mengalami transformasi pula. ${ }^{13}$

\section{Prinsip Motivasi}

Prinsip ini menempatkan motivasi pada posisi strategis terjadinya transformasi hukum. Contoh kasus dalam prinsip ini adalah pemberian kelebihan uang atau barang dari kreditur kepada debitur, jika motivasinya untuk dijadikan sebagai ungkapan rasa terimakasih tanpa ada transaksi dari kedua belah pihak terlebih dahulu sebelum akad kredit adalah diperbolehkan. Artinya, boleh bagi pemberi

${ }^{13}$ Ibnu al-Qayyim, Op. Cit, hlm. 16 
dan halal bagi penerima. Namun demikian, jika motivasinya adalah untuk dijadikan sebagai pemberian wajib yang ditransaksikan sebelumnya, maka hukumnya berubah menjadi haram bagi pemberi dan penerimanya. Secara sosiologis, motivasi seseorang atau masyarakat untuk melakukan sesuatu tindakan hukum ada beberapa kemungkinan. Tindakan itu dilakukan untuk penyesuaian diri, mendapatkan imbalan atau menghindari sanksi. Untuk menjaga hubungan baik dengan anggota masyarakat lainnya, kepentingan pribadi yang menguntungkan dan faktor penjiwaan dan penghayatan nilai dari tindakan hukum itu sendiri sebagai motivasi tertinggi dan termulia. ${ }^{14}$

Dengan demikian, motivasi pelaku suatu perilaku tertentu karena perbuatan itu sendiri yang secara inheren memiliki nilai esensial baik atau buruk. Namun demikian, menurut persepsi Hukum Islam, nilai perbuatan dan perilaku itu ditentukan oleh panduan wahyu, dalam hal ini panduan wahyu selaras dengan panduan nalar dan panduan indrawi. Oleh karena itu, motivasi perilaku karena perbuatan itu sendiri juga tercakup perambahan jaringan religius ilahiah. $^{15}$

\section{Prinsip Tadisi}

Ibnu al-Qayyim menyatakan bahwa transformasi Hukum Islam itu selaras dengan transformasi tradisi. Prinsip ini memberi posisi terhormat bagi tradisi sebagai pemegang kunci transformasi Hukum Islam. Artinya, jika terjadi perubahan tradisi, perubahan itu akan diikuti oleh perubahan Hukum Islam. Untuk memperjelas prinsip tradisi dalam konteks transformasi hukum Islam ini Ibnu al-Qayyim menyampaikan teori " Transformasi Hukum Suatu Kasus Berdasarkan pada Perilaku Tradisi, Amal Urf'.

Secara aplikatif, prinsip ini dapat dicermati pada kasus transformasi penetapan hukum suatu tindakan dan perilaku yang didasarkan pada perilaku dan tindakan tradisi. Ibnu al-Qayyim menyatakan bahwa apabila ada masyarakat yang bersumpah pantang atau bersumpah tidak mau makan kepala yang secara tradisi dimaksudkan untuk tidak makan kepala biri-biri, maka dapat ditetapkan tidak boleh ( haram) bagi mereka makan kepala biri-biri, tetapi tidak

${ }^{14}$ Soerjono Soekanto, Pokok-Pokok Sosiologi Hukum. Jakarta: Raja Grafindo Persada, 2003, hlm. 237240.

${ }^{15}$ Harun Nasution, Islam Ditinjau dari Berbagai Aspeknya, Jilid II, Jakarta:UI Press, 2002, hlm. 85. haram kepala binatang yang lain seperti kepala burung, ikan, dan lain-lain.

Dengan demikian Ibnu al-Qayyim tegas-tegas berprinsip bahwa penetapan hukum tentang perilaku yang sudah mentradisi harus didasarkan pada rasa keadilan hukum tradisi, selagi panduan syara' dalam keadaan netral atau vakum.

Secara sosiologis, tradisi atau istiadat merupakan bentuk kontrol sosial tertua dibanding yang lain.Tradisi merupakan seperangkat prosedur yang muncul secara bertahap dari generasi kegenerasi lainnya sampai menjadi keyakinan sosial. ${ }^{16}$

\section{Epistemologi Hukum Islam Dalam Menjawab Perubahan Zaman \\ 1. ljtihad}

Dinamika sosial dan zaman terus berubah. Sementara al-Quran dan Hadis sudah selesai turunnya. Sehingga diperlukan suatu epistemologi Hukum Islam untuk menjawab problematika kehidupan yang belum tercover oleh al-Quran dan Hadis secara jelas. Disinilah pentingnya ijtihad Hukum Islam yang dengannya penggalian dan penetapan hukum dapat dilakukan secara maksimal dengan berusaha menangkap makna dan pesan al-Quran dan Hadis. ${ }^{17}$

Keberadaan Hukum Islam seringkali tidak dibarengi dengan pemahaman yang memadai terhadap substansinya melalui cara ijtihad. Sehingga akibat yang muncul adalah adanya stagnansi pada ilmu-ilmu keislaman, hususnya yang berkaitan dengan Hukum Islam. Corak yang muncul dari pemikiran Hukum Islam Seperti ini adalah legal formalistik. Hal itu sudah lama terjadi, terutama setelah abad $10 \mathrm{M}$. Pemahaman yang mengatakan bahwa fiqh yang ada sudah mencakup hukum-hukum Allah telah menghambat usaha ijtihad, dan sebaliknya tradisi taqlid buta tumbuh secara subur. Kondisi seperti ini semakin parah ketika Hukum Islam yang merupakan hasil dari interpretasi nash dianggap teks yang otoritatif. Padahal tidak jarang, teks tersebut hanya merupakan komentar atau bahkan mungkin komentar atas komentar sehingga teks pertama justru menjadi hilang. Pada gilirannya, rumusan Hukum Islam kehilangan relevansinya dengan realitas kehidupan praktis. ${ }^{18}$

${ }^{16}$ Karl Manheim, Sosiologi Sistematis, Cet. I, terj.Jakarta: Bina Aksara, 1987, hlm. 143.

${ }^{17}$ Lihat: Fazlur Rahman, Islam and Modernity: Transformation of an Intellectual Tradition, Chicago: Chicago University Press, 1980, hlm. 6.

${ }_{18} \mathrm{John}$ L.Esposito, The Islamic Treat, terj. Alawiyah Abdur Rahman, Bandung: Mizan, 1994, hlm. 46. 
Dalam dinamika historitas Islam, ijtihad sebagai media dinamisasi Hukum Islam sangat progresif, bebas tanpa adanya aturan formal yang mengikutinya. Namun dalam perkembangannya, ulama ushul fiqh membuat aturan-aturan yang diantaranya berupa pembatasan ruang lingkup dan syarat-syarat ijtihad. Secara garis besar, wilayah ijtihad ini meliputi dua hal: pertama, hukum-hukum yang tidak ada petunjuk nashnya sama sekali; dan kedua, hukumhukum yang ditunjuk oleh nash zhanny. Sedangkan hukum-hukum yang telah ditunjuk dengan qath'i al-dalalah tidak ada sedikitpun peluang bagi ijtihad. ${ }^{19}$

Pembatasan terhadap lapangan hukum yang boleh dilakukan ijtihad dan tidak boleh ijtihad sebenarnya adalah hal yang baik. Begitu pula persyaratan-persyaratan bagi seorang mujtahid juga baik, supaya orang hati-hati dalam merumuskan hukum. ${ }^{20}$ Namun disisi lain, dibatasinya lapangan ijtihad menyebabkan pembaruan Hukum Islam bersifat parsial ad hoc. Karena untuk mewujudkan pembaruan secara universal diperlukan adanya pemberian ruang gerak ijtihad seluas-luasnya.

Dalam ijtihad, teks al-Quran dan Hadis dapat dipahami untuk digeneralisasikan sebagai prinsip-prinsip dan bahwa prinsipprinsip tersebut lalu dapat dirumuskan menjadi aturan-aturan yang baru. Dalam mekanisme kerja ijtihad meliputi pemahaman teks dalam keutuhan konteknya di masa lampau, pemahaan situasi baru yang sedang terjadi sekarang, dan perubahan aturanaturan hukum yang terkandung didalam teks. Reformulasi metode ijtihad tersebut dimanfaatkan sebagai upaya dari sebuah usaha pembaharuan Hukum Islam dan sekaligus sebagai usaha menjawab problem perkembangan zaman.

\section{Pembagian ljtihad}

Harus diakui bahwa masalah-masalah yang muncul sekarang adakalanya sudah ada atau mirip dengan yang tercantum dalam kitab-kitab klasik karangan ulama terdahulu, tetapi ada juga banyak kasus yang belum dibahas ulama atau mujtahid terdahulu. Berkenaan dengan keadaan tersebut, ijtihad

${ }^{19}$ Ad-Dawalibi, al-Madkhal ila IIm Ushulal-Fiqh, Damaskus: Dar al-Basyar al-Islamiyat, cet. 3, 1979, hlm. 414.

${ }^{20}$ Syarat-syarat mujtahid antara lain adalah; 1Mengetahui bahasa Arab dan berbagai aspeknya, misalnya nahwu, shorof, balaghah, mantiq dan lain sebagainya.2Mengetahui Ilmu al-Quran dan cabang-cabangnya, misalnya ilmu asbab al-nuzul, tafsir, ilmu tafsir, dan lain sebagainya. 3Memahami hadis dan cabang-cabangnya, misalnya ilm jarh wa al-ta'dil, ilmu asbabul wurud, dan lain sebagainya. Lihat: As-Syatibi,al-Muwafaqat fi Ushul al-Syariah. Riyadh: Maktabah Musthafa al-Baz, juz 2,hlm. 346. pada masa sekarang dapat dilakukan melalui dua cara, yaitu ijtihad intiqa'i dan ijtihad insya'i. ${ }^{21}$

a. Ijtihad Intiqa'i atau ljtihad Tarjihi

Yang dimaksud dengan ljtihad intiqa'i atau ijtihad tarjihi adalah ijtihad yang dilakukan secara individu maupun kelompok dalam rangka menyeleksi dan memetakan pendapat ulama pada masa lalu yang berkaitan dengan suatu jenis masalah yang termuat dalam kitab-kitab fiqh, dari penelusuran tersebut lalu dipilih mana pendapat yang paling kuat dan sesuai dengan perkembangan zaman. Ada kemungkinan pendapat ulama atau mujtahid terdahulu yang berkaitan dengan suatu masalah tertentu itu tidak sama. Menyikapi masalah seperti ini mujtahid muntaqi berusaha mencermati, mempertimbangkan dan menyeleksi dalil dan berbagai argumentasiyang dibangun dari masing-masing pendapat, setelah itu langkah berikutnya adalah membuat preferensi terhadap pendapat yang dinilai lebih kuat dan dapat diterima. Sepertinya, mujtahid tipe ini hampir sama dengan ahlu al-tarjih dalam pengelompokan tingkatan mujtahid yang disampaikan ulama atau ahli ushul figh pada umumnya. ${ }^{22}$

Apa yang dilaksanakan ahlu altarjih pada masa kebangkitan kembali hukum Islam berbeda dengan kegiatan tarjih pada masa kemunduran Hukum Islam. Pada masa kemunduran Hukum Islam, tarjih diartikan sebagai kegiatan yang tugas pokoknya adalah menyeleksi pendapat para ahli figh di lingkungan mazhab tertentu. Artinya ruang lingkup tarjih hanya berlaku dikalangan intern mazhab tertentu, seperti Hanafiyah, Malikiyah, dan lain-lain. Sedangkan tarjih pada masa kebangkitan kembali Hukum Islam ruang lingkupnya jauh lebih luas dari tarjih sebelumnya. Tarjih pada periode ini berarti menyeleksi berbagai pendapat, dari mazhab apapun ia berasal, kemudian diambil pendapat yang rajih, yang paling kuat, berdasarkan kriteria yang telah ditetapkan. Coulson dan Anderson menyebutnya sebagai electic expedient. Jadi lebih bersifat lintas mazhab, tidak terbatas pada mazhab tertentu. ${ }^{23}$

${ }^{21}$ Yusuf Qardawi, al-litihad fi al-Syariat al-Islamiyat ma'a Nazharatin Tahliliyat fi al-ljtihad al-Muashir, Kuwait: Dar al-Qalam, 1985, hlm. 101.

${ }^{22}$ Pengelompokan tingkatan mujtahid dapat dilihat di bukunya Abu Zahrah, Ushul Fiqh, tt: Dar al-Fikr al-Arabiy, tth, hlm. 396.

${ }^{23}$ Lihat: N.J. Coulson, A History of Islamic Law, Edinburg: Edinburg University Press, 1964, hlm. 185. 
Dalam rangka melakukan ijtihad intiqai ini sebaiknya kita tidak membatasi diri pada mazhab yang empat saja, melainkan harus menjangkau berbagai mazhab lain, baik yang telah dikenal atau tidak. Yang perlu diteliti dan diperhatikan bukan siapa yang mengatakannya, tetapi bagaimana dalil dan cara berpikir yang digunakan, bagaimana relevansinya dengan masa sekarang, dan bagaimana pula hubungannya dengan maqashid alsyariah.

Contoh dari ijtihad intiqai adalah masalah yang berhubugan dengan thalaq atau perceraian. Menurut mayoritas ulama ahli figh, thalaq dinyatakan jatuh apabila diucapkan oleh suami kepada istrinya dalam keadaan sadar dan atas kehendak sendiri, tanpa harus tergantung pada adanya saksi. ${ }^{24}$ Akan tetapi, menurut ahli fiqh dari kalangan Syi'ah, thalaq baru dianggap terjadi kalau disaksikan oleh dua orang saksi yang adil. ${ }^{25}$ Agaknya untuk masa sekarang pendapat Syi'ah itu dengan segala modifikasinya bisa dipertimbangkan.

Faktor-faktor yang harus diperhatikan oleh mujtahid muntaqi adalah perubahan sosial budaya, kemajuan ilmu pengetahuan dan teknologi, dan kesesuaian dengan perkembangan zaman. Faktor-faktor tersebut dapat dijadikan bahan pertimbangan dalam menyelesaikan masalah yang sedang ditetapkan hukumnya. Jadi, dalam pelaksanaan ijtihad intiqa'i diperlukan analisis yang cermat terhadap masalah yang sedang dikaji. Analisis tidak hanya terbatas pada dalil dan argumentasi yang dikemukakan para ulama ahli fiqh terdahulu, melainkan juga harus melihat relevansinya dengan masa sekarang.

b. ljtihad Insya'i

Yang dimaksud dengan ljtihad Insyai adalah usaha untuk menetapkan suatu hukum yang berkaitan dengan peristiwa-perisrtiwa baru yang belum ada atau belum pernah diselesaikan oleh para ulama ahli figh terdahulu. ${ }^{26}$ Yang diperlukan dalam ijtihad ini adalah pemahaman meyeluruh terhadap kasuskasus baru yang akan ditetapkan hukumnya. Karena tanpa mengetahui secara baik apa dan bagaimana kasus yang baru itu, sulit bagi mujtahid munsyi' untuk dapat menetapkan hukumnya

${ }^{24}$ Sayyid Sabiq, Fiqh al-Sunnah, Beirut: Daral-Fikr, tth, jilid II, hlm. 220.

${ }^{25}$ Ayatullah al-Uzma al-Syairazi, al-Figh Mausuat Istidlaliyat fi al-Fiqh al-Islami, Beirur: Darul Ulum, 1988, juz VI, hlm. 227.

${ }^{2626}$ Yusuf Qardawi,Op. Cit., hlm. 126. dengan baik dan benar. Jadi, dalam menghadapi persoalan yang sama sekali baru diperlukan pengetahuan mengenai masalah yang sedang dibahas, disamping pengetahuan yang menjadi persyaratan ijtihad itu sendiri. Dalam hubungan ini, ijtihad jama'i (ijtihad kolektif), mutlak diperlukan. Karena keterbatasan pengetahuan seseorang disertai semakin ketatnya disiplin ilmu pada masa sekarang. Sehingga ijtihad fardi (ijtihad individual) mengenai kasus yang sama sekali baru, akan kurang maksimal bahkan kemungkinan besar akan membawa kepada kekeliruan.

Contoh dari ijtihad model ini adalah pencangkokan jaringan atau organ tubuh manusia. Guna menetapkan hukumnya, perlu didengar lebih dahulu pendapat ahli dalam bidang kedokteran, hususnya ahli bedah. Dari padanya akan dapat diperoleh informasi mengenai cara dan mekanisme pencangkokan organtubuh itu. Setelah diketahui secara jelas, baru dibahas perihal pencangkokan itu dari berbagai disiplin ilmu agama Islam, untuk kemudian diambil kesimpulan hukumnya. Kegiatan ijtihad kolektif ini harus ditempuh, mengingat sudah semakin jelas dan tegasnya pembidangan ilmu yang didalami oleh seseorang.

Dalam ijtihad insya'i juga diperluan pemahaman yang baik tentang metode penetapan hukum. Ada beberapa metode penetapan yang telah dikemukakan oleh para ahli ushul figh terdahulu. Diantara metode itu adalah qiyas, istihsan, maslahat mursalah, dan saddu al-zari'ah. Hal lain yang perlu mendapat perhatian dari orang yang akan melakukan ijtihad insya'i adalah pengetahuan tentang tujuan disyariatkannya Hukum Islam, sebab pada dasarnya semua metode penetapan Hukum Islam bermuara pada hal tersebut.

\section{Qiyas}

Secara etimologis, kata qiyas berarti al-taqdir dan al-musawat yang artinya membandingkan atau menyamakan. Sedangakan secara istilah banyak disampaikan oleh para ulama ushul figh. Misalkan yang disampaikan oleh al-Baidhawi, qiyas adalah menetapkan semisal hukum yang diketahui pada sesuatu yang lain diketahui, karena keduanya berserikat dalam 'illat hukum menurut pandangan ulama yang menetapkan. ${ }^{27}$

${ }^{27}$ Syamsuddin Abd rahman al-Asfahani, Syarh alMinhaj li al-Baidhawi Fi al-ilm al-Ushul, jilid II. Riyadh: Maktabah al-Rusd, t.th, hlm. 634 
Berdasarkan rumusan tersebut, qiyas mempunyai empat rukun, yaitu 'ashl atau pokok atau maqis alaih, furu', hukum 'ashl dan 'illat. Dari empat rukun tersebut, 'illat paling memegang peranan penting. Karena adanya hukum dan tidak adanya tergantung dari adanya 'illat.

Dalam masalah 'illat ini sering terjadi kesalahan, yaitu menyamakan antara 'illat dan hikmah. Illat adalah suatu sifat tertentu yang jelas dan dapat diketahui secara obyektif (zhahir), dapat diketahui dengan jelas tolok ukurnya (mundabith), dan sesuai dengan ketentuan hukum (munasib), yang keberadaannya merupakan penentu adanya hukum. Sedangkan hikmah adalah menjadi tujuan atau maksud disyariatkannya hukum, dalam wujud kemaslahatan bagi manusia. ${ }^{28}$

Sementara al-Syatibi berbeda dengan jumhur ulama ushul figh, dimana ia berpendapat bahwa yang dimaksud dengan 'illat adalah hikmat itu sendiri, dalam bentuk mashlahat dan mafsadah, yang berkaitan dengan ditetapkannya perintah, larangan atau keizinan, baik keduanya itu zhahir atau tidak, mundhabith atau tidak. Jadi, baginya 'illat itu tidak lain kecuali adalah mashlahat dan mafsadat itu sendiri. Kalau demikian halnya, maka baginya hukum dapat ditetapkan berdasarkan hikmat, tidak berdarkan 'illat.

Sebenarnya hikmat dengan 'illat mempunyai hubungan yang erat dalam rangka penetapan hukum. Hikmat merupakan sifat yang zhahir tetapi tidak mundhabith. Hikmat itu baru akan menjadi 'illat setelah dinyatakan mundhabith. Untuk itu maka perlu dicari mazhinnatnya, yaitu indikator yang menerangkan bahwa hikmat itu dapat dinyatakan mundhabith. ${ }^{29}$

Dalam bidang ibadah contoh yang sering digunakan oleh kebanyakan ahli ushul figh adalah mengenai shalat qashar. Untuk menetapkan boleh atau tidaknya shalat qashar telah ditetapkan, bahwa safar atau bepergian merupakan illat dibolehkannya shalat qashar. Sedangkan masyaqat atau kesulitannya merupakan hikmat dibolehkannya shalat tersebut. Jadi boleh atau tidaknya melakukan shalat qashar, menurut mereka, tergantung ada atau tidaknya 'illat, yakni bepergian, sebab bepergian dianggap sebagai indikator (mazhinnat) adanya masyaqat.

Sedangkan dalam bidang muamalah, biasanya dikemukakan contoh tentang hak syuf'at, yakni hak pembelian bagi seseorang

${ }^{28}$ Lihat Wahbah Zuhaili, al-Wasith fi ushul al-Fiqh, Dimasyqi: al-Mathbaat al-Ilmiyyat, 1969, hlm. 415.

${ }^{29}$ Al-Baghdadi, Qawaid al-Ushul wa ma'aqid al-ushul. Beirut: Alam al-Kutub, 1986, hlm. 34. yang berserikat dengan penjual dalam sebidang tanah atau tempat tinggal. Dalam hal ini persekutuan merupakan 'illat adanya hak syuf'at. Sedangkan hikmatnya adalah untuk menghindari kesulitan yang timbul disebabkan masuknya orang lain yang bukan sekutunya. Dengan demikian, persekutuan dijadikan sebagai 'illat adanya hak syuf'at, karena diasumsikan bahwa karena masuknya unsur lain dalam persekutuan itu akan terjadi kesulitan. Pernyataan terakhir ini dianggap sebagai mazhinnat. ${ }^{30}$

Walaupun diatas dikemukakan dua contoh yang mewakili dua aspek ilmu fiqh, ibadah dan muamalah, namun perlu dibedakan antara 'illat dalam bidang ibadah dan 'illat dalam bidang muamalah. Dalam bidang ibadah, 'illat tidak lebih dari sekedar manfaat, tidak ada pengaruhnya terhadap istinbath al-hukm. Dengan kata lain 'illat dalam bidang ibadah tidak efektif. Karena itu pada dasarnya qiyas dalam bidang ibadah tidak dapat diberlakukan. Sedangkan dalam bidang muamalah, iilat berlaku efektif dalam menetapkan hukum. Hal ini didasarkan pada teori, bahwa pada dasarnya aspek muamalah dapat diketahui hikmat dan rahasianya (ma'qul al-makna), sedangkan dalam aspek ibadah tidak demikian. Praktis qiyas merupakan metode yang sering digunakan dalam hukum yang menyangkut bidang muamalah.

\section{SIMPULAN}

Hukum Islam mempunyai dua sifat, yaitu al-tsabat (tetap) dan al-tathawwur (berkembang). Sifat pertama, yaitu Hukum Islam sebagai wahyu Allah yang tetap dan tidak berubah sepanjang masa, sedangkan sifat yang kedua, yaitu Hukum Islam yang berkembang, tidak kaku dalam berbagai situasi dan kondisi sosial. Dalam keterpaduan antara dua sifat itulah Hukum Islam dapat bertahan sepanjang masa. Sifat yang pertama disebut syariah. Sedangkan sifat yang kedua disebut figh, yaitu pemahaman dari syariah.

Dalam menjawab tuntutan zaman yang terus berubah, dalam tulisan ini diketengahkan dua epistemologi Hukum Islam, yaitu ijtihad dan qiyas. Dengan kedua metode tersebut segala persoalan ditengah-tengah masyarakat dapat dipecahkan, walaupun secara yurisprudensi hukum dari persoalan tersebut tidak ada.

Dengan qiyas segala hukum furu dicarikan rujukan kepada hukum ashal. Sedangkan ijtihad untuk masa sekarang dapat dilakukan dengan dua cara, yaitu ijtihad Intiqa'i dan ijtihad insya'i. ljtihad Insya'i adalah ijtihad yang dilakukan seseorang atau sekelompok orang dengan cara memilih hukum masa lalu

${ }^{30}$ Abu Zahrah, Op.Cit, hlm. 237. 
yang sesuai dengan kondisi sekarang. Sementara ijtihad insya'i adalah sebuah ijtihad untuk memecahkan masalah baru yang belum diselesaikan oleh para ahli figh terdahulu.

\section{DAFTAR PUSTAKA}

Abu al-Hasan Ahmad Faris bin Zakariya, Mu'jam Maqayis al-Lughah. Mesir:Musthafa alBabi al-Halabi, 1970, jilid II.

Abu Dawud, Sunan Abu Dawud, jilid IV, 1998. Bandung:Dahlan Press.

Abu Zahrah, Ushul Fiqh, tt: Dar al-Fikr al-Arabiy, tth.

Ad-Dawalibi, al-Madkhal ila IIm Ushulal-Fiqh, Damaskus: Dar al-Basyar al-Islamiyat, cet. 3, 1979.

Ahmad Minhaji, "Reformasi Hukum Islam", Aula, Vol, III, No. 2, 1994.

Al-Baghdadi, Qawaid al-Ushul wa ma'aqid alushul. Beirut: Alam al-Kutub, 1986

Amir Syarifuddin, Pembaharuan Pemikiran Hukum Islam, cet. III, Padang:Angkasa Raya, 2005.

As-Syatibi, al-Muwafaqat fi Ushul al-Syariah. Riyadh: Maktabah Musthafa al-Baz, juz 2.

Ayatullah al-Uzma al-Syairazi, al-Fiqh Mausuat Istidlaliyat fi al-Fiqh al-Islami, Beirur: Darul Ulum, 1988, juz VI.

Fathurrahman Djamil, Filsafat Hukum Islam, cet. V, Jakarta: Logos Wacana IImu, 2013.

Fazlur Rahman, Islam and Modernity: Transformation of an Intellectual Tradition, Chicago: Chicago University Press, 1980.

Harun Nasution, Islam Ditinjau dari Berbagai Aspeknya, Jilid II, Jakarta:UI Press, 2002.

Hasbi As-I Shiddiqi, Fasfafah Hukum Islam, cet. IV, Jakarta: Bulan Bintang, 1993.

Ibn al-Qayyim, I'lam al-Muwaqqi'in, juz 3. Mesir: Maktabah Tijariyah al-Qahirah, 1955.

John L.Esposito, The Islamic Treat, terj. Alawiyah Abdur Rahman, Bandung: Mizan, 1994.

Karl Manheim, Sosiologi Sistematis, Cet. I, terj.Jakarta: Bina Aksara, 1987.

Muhammad Abu Zahrah, Ushul al-Fiqh. Mesir: Dar al-Fikr al-Arabi, 1958.

Muhammad Daud Ali, Hukum Islam: Pengantar IImu Hukum dan Tata Hukum Islam di Indonesia. Jakarta: PT Raja Grafindo, cet. XIII, 2013.

N.J. Coulson, A History of Islamic Law, Edinburg: Edinburg University Press, 1964.

Saifuddin al-Amidi, al-Ihkam fi Ushul al-Ahkam. Kairo: Muasassah al-Halabi, i967, jilid II.

Sayyid Sabiq, Fiqh al-Sunnah, Beirut: Daral-Fikr, tth, jilid III.

Soerjono Soekanto, Pokok-Pokok Sosiologi Hukum. Jakarta: Raja Grafindo Persada, 2003.
Syamsuddin Abd rahman al-Asfahani, Syarh alMinhaj li al-Baidhawi Fi al-'ilm al-Ushul, jilid II. Riyadh: Maktabah al-Rusd, t.th.

Wahbah Zuhaili, al-Wasith fi ushul al-Fiqh, Dimasyqi: al-Mathbaat al-Ilmiyyat, 1969.

Yusuf Qardawi, al-ljtihad fi al-Syariat al-Islamiyat ma'a Nazharatin Tahliliyat fi al-ljtihad alMuashir, Kuwait: Dar al-Qalam, 1985. 